
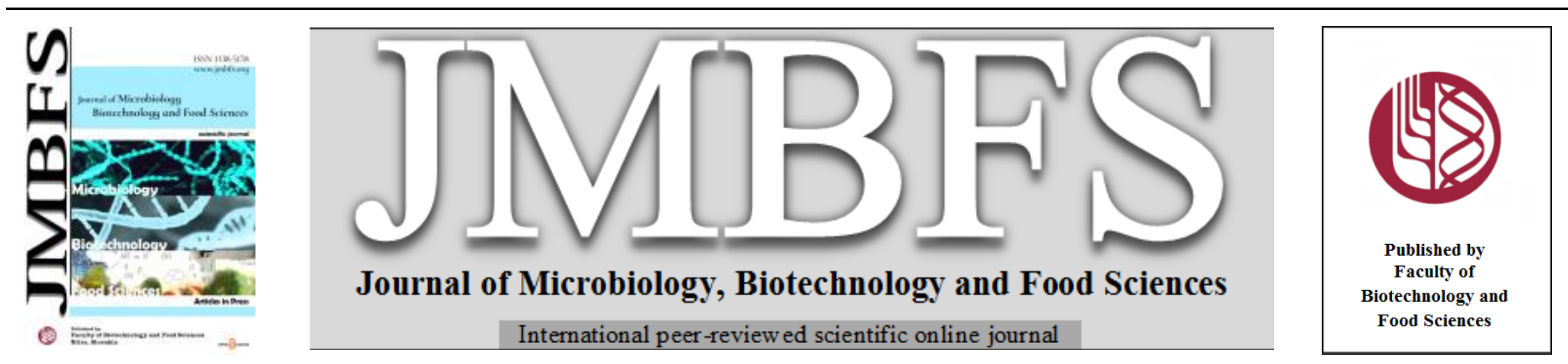

\title{
POTENTIAL EFFECT OF THYME AND OREGANO ESSENTIAL OILS TO ANTIMICROBIAL ACTIVITY AND YEAST ENZYMATIC ANTIOXIDATIVE SYSTEM
}

\author{
Anton Kovacik ${ }^{1, *}$, Miroslava Hlebova ${ }^{2}$, Lukas Hleba ${ }^{3}$, Tomas Jambor ${ }^{1}$, Eva Kovacikova ${ }^{4}$ \\ Address(es): \\ ${ }^{1}$ Institute of Applied Biology, Faculty of Biotechnology and Food Sciences, Slovak University of Agriculture in Nitra, Tr. A. Hlinku 2, 94976 Nitra, Slovak Republic. \\ ${ }^{2}$ Department of Biology, Faculty of Natural Sciences, University of Ss. Cyril and Methodius in Trnava, Nám. J. Herdu 2, Trnava, 917 01, Slovak Republic. \\ ${ }^{3}$ Institute of Biotechnology, Faculty of Biotechnology and Food Sciences, Slovak University of Agriculture in Nitra, Tr. A. Hlinku 2, 94976 Nitra, Slovak Republic. \\ ${ }^{4}$ AgroBioTech Research Centre, Slovak University of Agriculture in Nitra, Tr. A. Hlinku 2, 94976 Nitra, Slovak Republic.
}

*Corresponding author: anton.kovacik@yahoo.com,$\underline{\text { anton.kovacik@uniag.sk }}$

https://doi.org/10.15414/jmbfs.5583

ARTICLE INFO

Received 3. 3. 2021

Revised 7. 9. 2021

Accepted 15. 9. 2021

Published 1. 12. 2021

Regular article

open Aackess

\begin{abstract}
This in vitro study was aimed to assess the effects of Thymus vulgaris L. and Origanum vulgare L. essential oils (EOs) on cell viability and enzymatic antioxidative system in yeast Saccharomyces cerevisiae. Yeasts were cultivated with different concentrations of thyme (Thymus vulgaris L.) $(0.05-1.00 \mu 1 / \mathrm{ml})$ and oregano (Origanum vulgare L.) $(0.05-0.70 \mu 1 / \mathrm{ml})$ EOs for 24 hours. For the present study, gas chromatography-mass spectrometry (GC-MS) analysis was used to quantify chemical composition of EOs. The main components of thyme essential oil were caryophyllene (7.94\%), p-cymene (18.55\%), and thymol (46.55\%). In essential oil of oregano, there was found p-cymene $(8.43 \%)$ and carvacrol $(69.99 \%)$ mainly. The antimicrobial activity of selected EOs was investigated by the microbroth dilution method using 96 well microtiter plates. The most potent essential oil able to inhibit growth of Saccharomyces cerevisiae was oregano EO with the values of $\mathrm{MIC}_{50} 0.468845 \mu \mathrm{l} / \mathrm{ml}$ and $\mathrm{MIC}_{90} 0.501845 \mu \mathrm{l} / \mathrm{ml}$. Also, the activity of superoxide dismutase (SOD) and glutathione peroxidase (GPx) were assessed. According to our results, Thymus vulgaris $\mathrm{L}$. significantly increased the SOD levels at $0.2,0.4,0.5$ to $0.9 \mu \mathrm{l} / \mathrm{ml}$ and GPx production at 0.05 to $0.7 \mu 1 / \mathrm{ml}(P<0.001)$. In case of Origanum vulgare L., significant increase of SOD production at $0.05-0.2 \mu 1 / \mathrm{ml}(P<0.001)$ was observed. This essential oil also elevated GPx concentration in all experimental groups $(P<0.001)$ significantly. Data from this study suggest that selected EOs have significant effects on enzymatic antioxidants that may affect the firstline cell defense system against oxidative stress.
\end{abstract}

Keywords: Saccharomyces cerevisiae, MICs, Thymus vulgaris L., Origanum vulgare L., superoxide dismutase, glutathione peroxidase

\section{INTRODUCTION}

The antioxidant potential of plant bioactive substances has recently been in the high interest of the scientific and lay public. Plant antioxidants can inhibit the effect of free radicals, thus providing some protection against various diseases (Pratt, 1992; Amarowicz and Pegg, 2019) and are of interest to many scientific studies addressing the potential positive effects on the overall health status (Kiokias $\boldsymbol{e t}$ al., 2020; Manuelian et al., 2021), reproduction potential (Zhong and Zhou, 2013; Tvrdá et al., 2016; Vizzari et al., 2021) or endocrine system (Golbidi and Laher, 2010; Jambor et al., 2021).

Thymus vulgaris $\mathrm{L}$. is a plant species belonging to the genus Thyme (Lamiaceae family). Thyme extract or essential oil has been attributed to many beneficial effects on the human body. These are mainly antioxidative, anti-inflammatory, antitumoral, and antimicrobial effects (Nikolić et al., 2014; Yan et al., 2016; de Oliveira et al., 2017; He et al., 2020; Císarová et al., 2020). Thymus vulgaris $\mathrm{L}$. is an herb found in Europe, Africa, and Asia, where it is also widely used in folk medicine. Origanum vulgare $\mathrm{L}$. is an herb which also belongs to Lamiaceae family (genus Origanum) that grows in Europe, North Africa, and Asia. Oregano essential oils show, among other features, antioxidative (Spiridon et al., 2011), antimicrobial (De Martino et al., 2009), antifungal (Hlebová et al., 2021) or hepatoprotective (Oniga et al., 2018) activities.

Superoxide dismutase, glutathione peroxidase and catalase are the first line defense antioxidants (Ighodaro and Akinloye, 2018). While catalase is not present in mitochondria of most cells, superoxide dismutase and glutathione peroxidase are systems located in mitochondria (Bai and Cederbaum, 2001).

Yeasts are eukaryotic microorganisms that can be used as excellent cell model for basic research of redox markers. Their undoubted advantages are low cost and confirmed cell response to oxidative stress (Jamieson, 1998; Toledano et al., 2003).

Based on the above, aim of the present study was to evaluate potential antimicrobial and antioxidative activity of thyme and oregano essential oils (EOs). Effect of selected substances to redox markers production was investigated in yeast. At the same time the GC-MS profiling of thyme and oregano was attempted to understand their chemical composition associated with biologically active substances rendering them biological significance. This study provides a better understanding of underlying enzymatic antioxidant mechanisms of thyme and oregano essential oils.

\section{MATERIAL AND METHODS}

Yeast, media, growth conditions and identification (MALDI-TOF MS)

Saccharomyces cerevisiae isolated from commercial baker's yeast was used as the yeast strain in this study. For isolation of yeast strain, Sabourad dextrose agar (Biolife, Italy), $30 \pm 1^{\circ} \mathrm{C}$ during $24 \mathrm{~h}$ was used. Purification of yeast colonies was provided by four-way streak plate method. Isolated species was identified by using MALDI TOF MS (Maldi Biotyper, Bruker Daltonics, Germany) according to Hleba et al. (2017).

Chemical analyses of thyme (Thymus vulgaris L.) and oregano (Origanum vulgare L.) EOs (GC-MS)

The essential oils were obtained from commercial supplier Calendula a.s. (Nová Lubovna, Slovak Republic). EOs were prepared by hydrodistillation and stored in the dark at $4{ }^{\circ} \mathrm{C}$ in hermetically sealed bottles, before analyses. The chemical composition of EOs was conducted in an Agilent 7890A GC coupled to an Agilent MSD5975C MS detector (Agilent Technologies, Palo Alto, CA, USA) with an HP5MS column $(30 \mathrm{~m} \times 0.25 \mathrm{~mm}, 0.25 \mathrm{~m}$ film thickness). Essential oils were diluted in hexane to a concentration of $1 \mu \mathrm{l} / \mathrm{ml}$. The operating conditions were as follows: one microliter of the sample was injected in split mode 1:12, at an injector temperature of $250{ }^{\circ} \mathrm{C}$ and electron ionization energy of $70 \mathrm{eV}$. Analysis was measured in SCAN mode, mass range was $40-400 \mathrm{~m} / \mathrm{z}$. The oven temperature started at $60{ }^{\circ} \mathrm{C}$ to a maximum of $231^{\circ} \mathrm{C}$ at a rate of $3{ }^{\circ} \mathrm{C} / \mathrm{min}$, and then was kept constant for 10 min (Božik et al., 2017). The EOs constituents were identified by 
mass spectrometry (MS) and their identity was confirmed by comparing their Kovats retention indices $(\mathrm{KI})$ and their spectra with the retention time of the used authentic standards (Sigma-Aldrich, CZ) (Table1) or with data available in the National Institute of Standards and Technology Library (NIST, USA), and with literature (Adams, 2007). Only the EOs compounds over $0.1 \%$ were included.

\section{Antimicrobial activity of essential oils (cell viability)}

The antimicrobial activity of selected EOs was investigated by the microbroth dilution method by using 96 well microtiter plates according to Hleba et al. (2014). EOs were diluted in dimethyl sulfoxide (Sigma-Aldrich, Germany) directly into the Sabouraud broth medium (HiMedia, India). The 96 well microtiter plates were prepared by adding $100 \mu \mathrm{l}$ of SB medium with tested EOs. For minimum inhibitory concentrations (MICs) determination of EOs, two-fold dilutions of each EO at the concentration of 10 to $0,004883 \mu \mathrm{l} / \mathrm{ml}$ were used. Then a $100 \mu \mathrm{l}$ of yeast inoculum at the final density of $0.5 \mathrm{McF}$ arland were added to each well to give a final volume $200 \mu \mathrm{l}$. After $24 \mathrm{~h}$ incubation at $30^{\circ} \mathrm{C}$ the inhibition of microbial growth was evaluated by measuring the well absorbance at $450 \mathrm{~nm}$ in an absorbance microplate reader Biotek EL808 with shaker (Biotek Instruments, USA). The minimum inhibitory concentrations (MICs) were calculated based on growth control density and were the lowest EO concentrations that completely inhibited the yeast growth Control sets as the negative control (without yeast inoculum), growth control and purity of EOs were tested simultaneously with the samples. All experiments were carried out in triplicate, independently. The results shown in Table 2 present $\mathrm{MIC}_{50}$ and $\mathrm{MIC}_{90}$ of EOs and were obtained by the probit analysis using the SAS statistical program (confidence level 95\%, $P<0.05$ ).

\section{Superoxide dismutase (SOD) and glutathione peroxidase (GPx) activity assay}

Yeasts were cultivated with different concentrations of thyme $(0.05-1.00 \mu \mathrm{l} / \mathrm{ml})$ and oregano $(0.05-0.70 \mu \mathrm{l} / \mathrm{ml})$ EOs for 24 hours. Subsequently, the medium was removed from microtiter plates and centrifuged (1 $006 \mathrm{~g}$ for $10 \mathrm{~min}$ ). The supernatant was used for SOD and GPx quantification. Analyses were performed using Randox commercial kits (Randox Laboratories, Ltd., United Kingdom) and semi-automated analyzer Randox Rx Monza (Randox laboratories, Ltd., United Kingdom) (Tvrdá et al., 2016; Kovacik et al., 2019). The concentrations of the total protein (TP) were measured using DiaSys (Diagnostic Systems GmbH, Holzheim, Germany) commercial kits and the Randox RX Monza (Randox Laboratories, Ltd., United Kingdom) (Kovacik et al.,2020; Kovacikova et al., 2019). All experiments were carried out in triplicate, independently. The results are expressed as IU/g TP (units per gram of total protein).

\section{Statistical analyses}

Probit statistical evaluation was performed using Statgraphics software (STATGRAPHIC Centurion XV, Statgraphics Technologies, Inc., The Plains, Virginia, USA). By using obtained absorbance before and after the analysis, it was possible to express the differences in absorbance between the measurements as a set of binary values. These values were assigned to exact concentrations. Following formula was created for this specific experiment: value 1 (inhibitory effect) was assigned to absorbance values lower than 0.05 , while value 0 (no effect or stimulant effect) was assigned to absorbance values higher than 0.05 .

Statistical analyses were performed using the GraphPad Prism 6.01 (GraphPad Software Incorporated, San Diego, California, USA). All obtained data were tested for normality using Kolmogorov-Smirnov and Shapiro-Wilk test. Analysis of variance (One-Way ANOVA) followed by Dunnett's multiple comparison test was used for statistical evaluation. Results were expressed as the mean \pm standard deviation (S.D). The level of significance was set at $* * *(P<0.001), * *(P<0.01)$ and $*(P<0.05)$.

\section{RESULTS}

\section{Identification of thyme and oregano EOs chemical compounds}

Qualitative and quantitative analyses of EOs are listed in Table 1. The volatile components of tested EOs belong to monoterpenes, monoterpenoid phenols, monoterpenoids, and sesquiterpenes. The main components of thyme (Thymus vulgaris L.) essential oil were identified as caryophyllene $(7.94 \%)$, p-cymene $(18.55 \%)$, and thymol $(46.55 \%)$. In essential oil of oregano, there was found $p$ cymene $(8.43 \%)$ and carvacrol $(69.99 \%)$ mainly.

\section{Antimicrobial activity of thyme and oregano EOs}

For the determination of minimum inhibitory concentrations (MICs) values, lower concentrations $(10-0.004883 \mu \mathrm{l} / \mathrm{ml})$ of 2 essential oils, were used. The obtained results showed a different antifungal activity of tested EOs with $\mathrm{MIC}_{50}$ and $\mathrm{MIC}_{90}$ values estimated by probit analysis (Table 2).
Table 2 The minimum inhibitory concentrations $\left(\mathrm{MIC}_{50}\right.$ and $\mathrm{MIC}_{90} ; \mu \mathrm{l} / \mathrm{ml}$ ) for essential oils effective against Saccharomyces cerevisiae on SB at $30 \pm 1{ }^{\circ} \mathrm{C}$ after 24 hours of cultivation

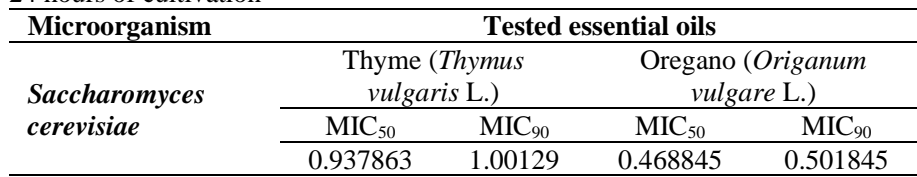

Oregano EO was found the most potent essential oil able to inhibit growth of Saccharomyces cerevisiae, with the values of $\mathrm{MIC}_{50} 0.468845 \mu \mathrm{1} / \mathrm{ml}$ and $\mathrm{MIC}_{90}$ $0.501845 \mu \mathrm{l} / \mathrm{ml}$

\begin{tabular}{|c|c|c|c|}
\hline $\mathbf{R I}^{\mathbf{a}}$ & Component & Thyme $^{\mathrm{c}}$ & Oregano \\
\hline 938 & ${ }^{\mathrm{b}} \alpha$-pinene & 1.22 & 0.33 \\
\hline 953 & bamphene & 1.31 & 0.29 \\
\hline 980 & b/pinene & 0.20 & \\
\hline 982 & 1-octen-3-ol & 0.66 & \\
\hline 993 & $\beta$-myrcene & 1.36 & 0.47 \\
\hline 997 & 3-octanol & & 0.21 \\
\hline 1006 & ${ }^{\mathrm{b}} \alpha$-phellandrene & 0.1 & \\
\hline 1019 & ${ }^{\mathrm{b}} \alpha$-terpinene & 1.2 & 0.91 \\
\hline 1029 & ${ }^{b}$ p-cymene & 18.55 & 8.43 \\
\hline 1031 & b-limonene & 0.36 & \\
\hline 1034 & beucalyptol & 1.47 & 1.19 \\
\hline 1062 & ${ }^{b} \gamma$-terpinen & 4.27 & 3.49 \\
\hline 1090 & bterpinolene & 0.13 & 0.12 \\
\hline 1101 & linalool & 3.89 & 3.19 \\
\hline 1147 & bcamphor & 1.98 & 0.89 \\
\hline 1168 & bborneol & 1.85 & 0.87 \\
\hline 1179 & b4-terpineol & 1.93 & 0.77 \\
\hline 1192 & $\alpha$-terpineol & 0.18 & 0.41 \\
\hline 1238 & thymol methyl ether & 0.70 & \\
\hline 1247 & b(-)-carvone & 1.1 & 0.10 \\
\hline 1296 & bthymol & 46.55 & 2.6 \\
\hline 1297 & menth-1-en-9-ol & 1.88 & \\
\hline 1306 & bcarvacrol & & 69.99 \\
\hline 1360 & beugenol & 0.22 & 0.15 \\
\hline 1376 & copaene & 0.16 & 0.14 \\
\hline 1420 & bcaryophyllene & 7.94 & 1.84 \\
\hline 1452 & ${ }^{\mathrm{b}} \alpha$-caryophyllene & & 0.45 \\
\hline 1505 & $\alpha$-bisabolene & & 0.11 \\
\hline 1524 & $\delta$-cadinene & 0.32 & 0.44 \\
\hline 1574 & baryophyllene oxide & 0.19 & 0.31 \\
\hline total & & 99.54 & 97.70 \\
\hline
\end{tabular}

Legend: ${ }^{\mathrm{a}}$ - RI: identification based on Kovats retention indices (HP-5MS capillary column) and mass spectra; ${ }^{\mathrm{b}}$ - Identification confirmed by co-injection of authentic standard; ${ }^{\mathrm{c}}$ - relative proportion were calculated in $\%$ by dividing individual peaks area by total area of all peaks.

\section{Effects of thyme EO on SOD and GPx activity of Saccharomyces cerevisiae}

Yeast cells were exposed to increasing doses of thyme EO $(0.05-1.0 \mu \mathrm{l} / \mathrm{ml})$ during $24 \mathrm{~h}$. As shown in Fig. 1, SOD levels were significantly higher $(P<0.001 \mathrm{resp}$ $\mathrm{P}<0.01$ ) in experimental groups (from 0.5 to $0.9 \mu \mathrm{l} / \mathrm{ml}$ ) in comparison to control.

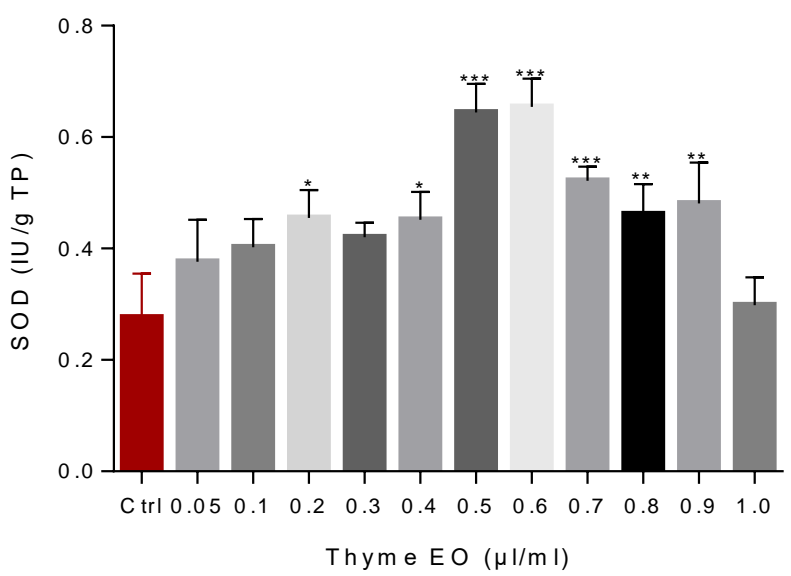

Figure 1 SOD production in yeast Saccharomyces cerevisiae cells exposed to different concentrations of experimental essential oil from Thymus vulgaris L. in vitro after $24 \mathrm{~h}$ cultivation. Ctrl - control group. Each bar represents the mean $( \pm$ S.D.) of control (untreated) and treated groups. 
Slight increases were recorded at 0.2 and $0.4 \mu 1 / \mathrm{ml}$ of thyme, also with significant changes $(P<0.05)$. At the highest dose of thyme, a statistically significant difference was not observed

A dose-dependent increase in the GPx production caused by thyme EO is shown in Fig. 2. An increase was recorded in all applied concentrations of thyme except for the highest concentrations $(0.8,0.9$ and $1.0 \mu \mathrm{l} / \mathrm{ml})$. Lower doses of the tested substance $(0.05-0.7 \mu 1 / \mathrm{ml})$ initiated a successive increase of GPx production $(P<0.001)$.

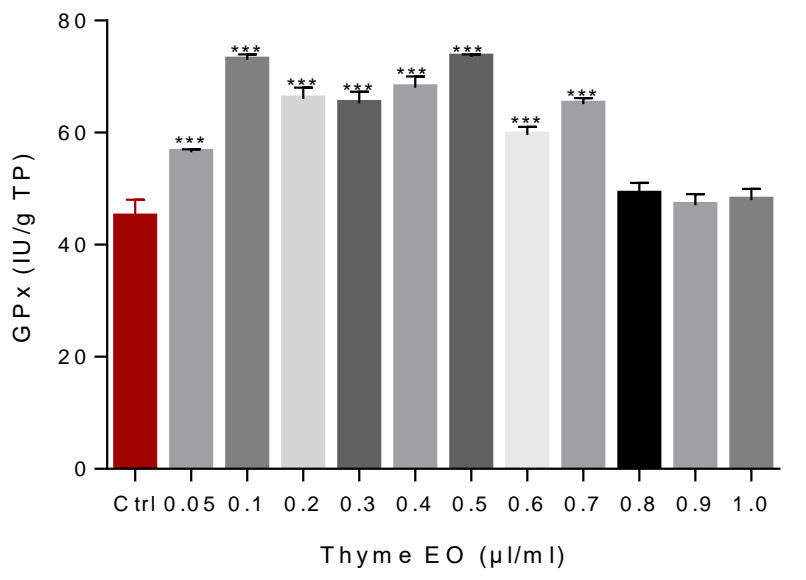

Figure 2 GPx production in yeast Saccharomyces cerevisiae cells exposed to different concentrations of experimental essential oil from Thymus vulgaris L. in vitro after $24 \mathrm{~h}$ cultivation. Ctrl - control group. Each bar represents the mean $( \pm$ S.D.) of control (untreated) and treated groups.

\section{Effects of oregano EO on SOD and GPx activity of Saccharomyces cerevisiae}

Yeast cells were exposed to increasing doses of oregano EO $(0.05-0.7 \mu 1 / \mathrm{ml})$ during $24 \mathrm{~h}$. A dose-dependent effect in the SOD production caused by oregano is shown in Fig. 3. Lower doses of the tested substance $(0.05-0.2 \mu 1 / \mathrm{ml})$ initiated an increase of SOD production, the differences were significant $(P<0.001)$. Higher doses of the oregano $\mathrm{EO}(0.5-0.7 \mu \mathrm{l} / \mathrm{ml})$ initiated a successive decrease compared to the control group.

The results shown in Fig. 4 illustrate that experimental doses from 0.05 to 0.7 $\mathrm{mg} / \mathrm{mL}$ did affect the GPx production significantly $(P<0.001)$. GPx production increased in all groups with increasing experimental dose of the test substance.

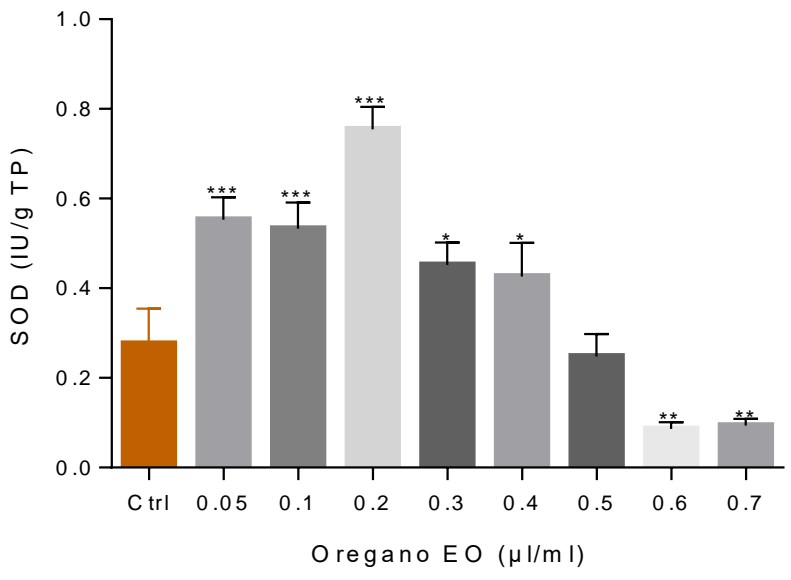

Figure 3 SOD production in yeast Saccharomyces cerevisiae cells exposed to different concentrations of experimental essential oil from Origanum vulgare L. in vitro after $24 \mathrm{~h}$ cultivation. Ctrl - control group. Each bar represents the mean ( \pm S.D.) of control (untreated) and treated groups.

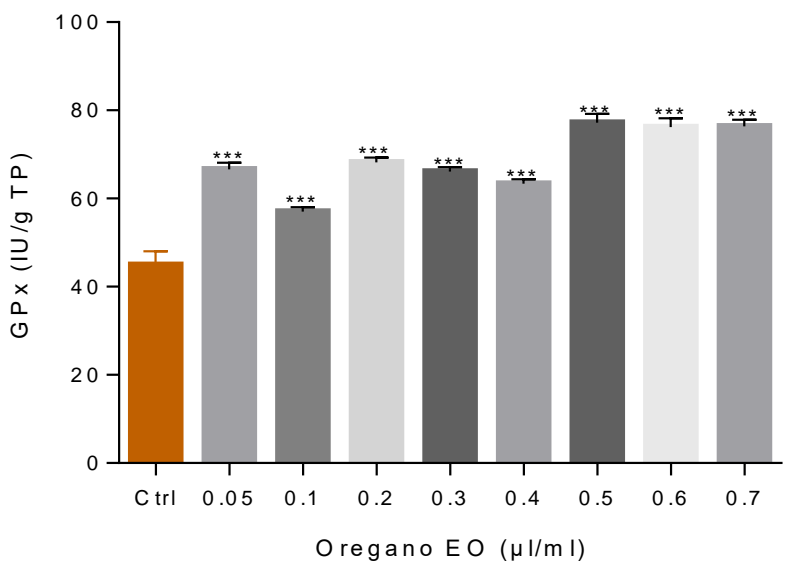

Figure 4 GPx production in yeast Saccharomyces cerevisiae cells exposed to different concentrations of experimental essential oil from Origanum vulgare L. in vitro after $24 \mathrm{~h}$ cultivation. Ctrl - control group. Each bar represents the mean ( \pm S.D.) of control (untreated) and treated groups

\section{DISCUSSION}

\section{Thyme and oregano EOs chemical compounds}

Chemical composition of thyme and oregano EOs, as well as other essential oils, is different and it depends on recovery or extraction methods and procedures (Sefidkon et al., 2006; Lis-Balchin et al., 1998), also on region (Sangun et al., 2007), plant varieties (Ložien et al., 2003) and plant parts (Alsaraf et al., 2020). Compared to other studies, we can confirm that composition of thyme EO is very different and varies from study to study. The main compositions in our thyme EO were thymol (46.55\%), p-cymene (18.55\%) and caryophyllene $(7.94 \%)$. Unlike us, authors Alsaraf et al., 2020 acquire thyme EOs by hydro-distillation from leaves and they identified the main compounds as carvacrol $(59.29 \%)$ and $y$-terpineme $(29.12 \%)$. On the other hand, authors Porte and Godoy, 2008 used hydrodistillation extraction method from leaves and they observed thymol $(44.7 \%)$, pcymene $(18.6 \%)$, y-terpineme $(16.5 \%)$ and caryophyllene $(0.8 \%)$ as the main compounds only. Absolutely different main compounds of thyme EOs obtained using hydro-distillation extraction method from dried areal parts of thyme plants by authors Imelouane et al., 2009 were determined. They detected camphor (38.54\%) and camphene $(17.19 \%)$ and $\alpha$-pinene $(9.35 \%)$ as main compounds of thyme EO. In the case of oregano EOs, carvacrol $(69.99 \%)$ and p-cymene $(8.43 \%)$ were identified as the main compounds. In contrary, authors Teixeira et al., 2013 identified carvacrol in amount of $14.5 \%$. Except for carvacrol, they detected $\gamma$ Terpinene (11.6\%), $\beta$-fenchyl alcohol $(12.8 \%)$ and thymol $(12.6 \%)$ as main compounds. Kulisic et al., 2004 obtained two fractions - hydrocarbons $\mathrm{CH}$ fraction and oxygen containing compounds fraction after fractionation of oregano essential oil using column chromatography separation. The main compounds of hydrocarbons $\mathrm{CH}$ fraction determined by HPLC were $\alpha$-terpinene $(10.4 \%), y$ terpinene $(31.0 \%)$ and p-cymene $(22.1 \%)$. Oxygen containing compounds fraction contained thymol $(47.3 \%)$ and carvacrol $(46.4 \%)$ as main compounds. Obviously, difference between main components of EOs is significant. Therefore, it is very important to determine the composition of all EOs tested in each new study.

\section{Antimicrobial activity of thyme and oregano EOs}

Antimicrobial activity of thyme and oregano EOs was tested on Saccharomyces cerevisiae by MIC method, where strong antimicrobial activity was observed. Similarly, Konuk et al., 2017 observed high antimicrobial effectivity of thyme and oregano EOs against $S$. cerevisiae. They determined minimal inhibition concentration at the level of $0.2-0.3 \mu \mathrm{l} / \mathrm{ml}$ for both EOs. Moreover, they also observed that all tested EOs increased extracellular $\mathrm{pH}$, possibly due to the neutralization of the glucose-induced $\mathrm{pH}$ gradient upon impairment of the cell membrane. Bennis et al., 2004 used pure thymol, which is a main compound of thyme EO, for inhibition of $S$. cerevisiae growth. For complete inhibition of $S$. cerevisiae growth, $3 \mathrm{mM}$ of thymol dispersed in $0.2 \%$ agar solution was sufficient Using concentration higher than MIC caused total mortality. Authors confirmed connection between total mortality of $S$. cerevisiae and lysis of yeast cells. Their observing by scanning electron microscopy clearly showed that surface of many cells is deformed significantly and cells in the background showed important damage consisting in apparent cracks. Antimicrobial activity of thyme and oregano EOs was confirmed by many authors (Farag et al., 1989; Özcan et al., 2001; Belletti et al., 2004; Bennis et al., 2004; Chami et al., 2005; Wang et al., 2011; Lv et al., 2011; Císarová et al., 2020; Hlebová et al., 2021). 
Action of thyme and oregano EOs on the antioxidant protection of Saccharomyces cerevisiae model cells

In our study, we also investigated the in vitro effect of selected EOs on antioxidant enzymes in $S$. cerevisiae. Thymus vulgaris $L$. and Origanum vulgare L., are characterized by the presence of numerous bioactive compounds such as monoterpenes, phenolic compounds, sesquiterpenes, thymol, isothymol and other metabolites (Lee et al., 2005; De Martino et al., 2009; Nikolić et al., 2014; Oniga et al., 2018). Bioactive compounds can inhibit the effect of free radicals, thus providing some protection against various diseases (Pratt, 1992; Nour et al. 2017; Amarowicz and Pegg, 2019). SOD, GPx and catalase are the first line defense antioxidant enzymes against oxidative stress (Ighodaro and Akinloye, 2018). We confirmed that some of the analyzed concentrations may affect SOD and GPx production in a dose-dependent manner.

There is a lack of studies on the specific effects of thyme and oregano on yeast. However, there are several experimental studies examining the effect of specific bioactive substances on yeast or other cell models. Comparable consequences have previously been reported by Khan $\boldsymbol{e t}$ al. (2015). Candida Albicans cells were exposed to two monoterpene phenols (thymol and carvacrol) at concentrations ranging from 5 to $20 \mu \mathrm{g} / \mathrm{ml}$. The studied phenols increased SOD activity statistically at all tested concentrations. GPx activity decreased significantly after initial increasing with growing concentrations of each compound. Ceker et al. (2012) evaluated the impact of Origanum vulgare $L$. EO on the human lymphocytes stressed by aflatoxin $\mathrm{B} 1\left(\mathrm{AFB}_{1}\right)$. Cells were cultured together with $\mathrm{AFB}_{1}$ and experimental concentrations of oregano EO $(0.1$ to $2.0 \mu \mathrm{l})$ for $72 \mathrm{~h}$ in vitro. Authors monitored, inter alia, the activity of SOD and GPX in the supernatan after essential oil application. Their results showed significant increases in the activities of SOD and GPX compared to control. Höferl et al. (2014) tested antioxidant protection of juniper berry EO on $S$. cerevisiae as the model organism Activities of SOD, GPx and CAT of yeast were higher (in some cases significantly) compared to controls and yeast treated with dimethylsulfoxid. A similar study was performed using ginger EO, where authors confirmed significant dose dependent increase of antioxidative enzymes and cell viability (Höferl $\boldsymbol{e t}$ al., 2015).

Several other studies describe the antioxidant potential of thyme and oregano EO or their compounds in different cell (Nikolić et al., 2014; Alsaraf et al., 2020 Avola et al., 2020; Mar et al., 2020) or animal models (El-Nekeety et al., 2011; He et al., 2020; Zhang et al., 2020). Phenolic and terpenoid compounds present in the chemical composition of EO are closely related to their antioxidant function. From the above, the considerable importance of plant essential oils, which deserve future research, is evident.

\section{CONCLUSION}

Essential oils can be considered a good source of natural bioactive compounds with antioxidant and antimicrobial effects. The main components of the monitored EOs were caryophyllene, p-cymene, thymol (in Thymus vulgaris L.) and p-cymene, carvacrol (in Origanum vulgare L.). Data from this study suggest that selected EOs have significant effects on enzymatic antioxidants that may affect the first-line cell defense system against oxidative stress. In our study, we shed a little more understanding the physiological processes taking place in $S$. cerevisiae cells based on the observed RedOX parameters. However, due to a lack of detailed examination of redox markers in yeast as a cell model, further experiments are needed.

Acknowledgment: This work was supported by the Slovak Research and Development Agency under the contract No. APVV-16-0289. This publication was also supported by the Operational program Integrated Infrastructure within the project: Demand-driven research for the sustainable and innovative food, Drive4SIFood 313011V336, co-financed by the European Regional Development Fund.

\section{REFERENCES}

Adams, R. P. (2007). Identification of essential oil components by gas chromatography/mass spectrometry (Vol. 456). Carol Stream, IL: Allured Publishing Corporation.

Alsaraf, S., Hadi, Z., Al-Lawati, W. M., Al Lawati, A. A., \& Khan, S. A. (2020). Chemical composition, in vitro antibacterial and antioxidant potential of Omani Thyme essential oil along with in silico studies of its major constituent. Journal of King Saud University-Science, 32(1), 1021-1028. https://doi.org/10.1016/j.jksus.2019.09.006

Amarowicz, R., \& Pegg, R. B. (2019). Natural antioxidants of plant origin. In Advances in food and nutrition research (Vol. 90, pp. 1-81). Academic Press. Avola, R., Granata, G., Geraci, C., Napoli, E., Graziano, A. C. E., \& Cardile, V. (2020). Oregano (Origanum vulgare L.) essential oil provides anti-inflammatory activity and facilitates wound healing in a human keratinocytes cell model. Food and Chemical Toxicology, 144,

111586

https://doi.org/10.1016/bs.afnr.2019.02.011

Bai, J., \& Cederbaum, A. I. (2001). Mitochondrial catalase and oxidative injury. Neurosignals, 10(3-4), 189-199. https://doi.org/10.1159/000046887
Belletti, N., Ndagijimana, M., Sisto, C., Guerzoni, M. E., Lanciotti, R., \& Gardini, F. (2004). Evaluation of the antimicrobial activity of citrus essences on Saccharomyces cerevisiae. Journal of Agricultural and Food Chemistry, 52. https://doi.org/10.1021/jf049444v

Bennis, S., Chami, F., Chami, N., Bouchikhi, T., \& Remmal, A. (2004). Surface alteration of Saccharomyces cerevisiae induced by thymol and eugenol. Letters in Applied Microbiology, 38(6), 454-458. https://doi.org/10.1111/j.1472 765X.2004.01511.X

Božik, M., Císarová, M., Tančinová, D., Kouřimská, L., Hleba, L., \& Klouček, P. (2017). Selected essential oil vapours inhibit growth of Aspergillus spp. in oats with improved consumer acceptability. Industrial Crops and Products, 98, 146 152. https://doi.org/10.1016/j.indcrop.2016.11.044

Ceker, S., Agar, G., Nardemir, G., Anar, M., Kizil, H. E., \& Alpsoy, L. (2012) Investigation of anti-oxidative and anti-genotoxic effects of Origanum vulgare L. essential oil on human lymphocytes in vitro. Journal of Essential Oil Bearing Plants, 15(6), 997-1005. https://doi.org/10.1080/0972060X.2012.10662604

Chami, F., Chami, N., Bennis, S., Bouchikhi, T., \& Remmal, A. (2005). Oregano and clove essential oils induce surface alteration of Saccharomyces cerevisiae. Phytotherapy Research: An International Journal Devoted to Pharmacological and Toxicological Evaluation of Natural Product Derivatives, 19(5), 405-408. https://doi.org/10.1002/ptr.1528

Císarová, M., Hleba, L., Medo, J., Tančinová, D., Mašková, Z., Čuboň, J., Kováčik, A., Foltinová, D., Božik, M. \& Klouček, P. (2020). The in vitro and in situ effect of selected essential oils in vapour phase against bread spoilage $\begin{array}{llll}\text { toxicogenic } & \text { aspergilli. Food } & \text { Control, 110, }\end{array}$ https://doi.org/10.1016/j.foodcont.2019.107007

De Martino, L., De Feo, V., Formisano, C., Mignola, E., \& Senatore, F. (2009) Chemical composition and antimicrobial activity of the essential oils from three chemotypes of Origanum vulgare L. ssp. hirtum (Link) Ietswaart growing wild in Campania $\quad$ (Southern $\quad$ Italy). Molecules, 14(8), 2735-2746. https://doi.org/10.3390/molecules14082735

de Oliveira, J. R., de Jesus Viegas, D., Martins, A. P. R., Carvalho, C. A. T., Soares, C. P., Camargo, S. E. A., ... \& de Oliveira, L. D. (2017). Thymus vulgaris L. extract has antimicrobial and anti-inflammatory effects in the absence of cytotoxicity and genotoxicity. Archives of oral biology, 82, 271-279. https://doi.org/10.1016/j.archoralbio.2017.06.031

El-Nekeety, A. A., Mohamed, S. R., Hathout, A. S., Hassan, N. S., Aly, S. E., \& Abdel-Wahhab, M. A. (2011). Antioxidant properties of Thymus vulgaris oil against aflatoxin-induce oxidative stress in male rats. Toxicon, 57(7-8), 984-991.

Farag, R. S., Daw, Z. Y., Hewedi, F. M., \& El-Baroty, G. S. A. (1989). Antimicrobial activity of some Egyptian spice essential oils. Journal of food protection, 52(9), 665-667. https://doi.org/10.1016/j.toxicon.2011.03.021

Golbidi, S., \& Laher, I. (2010). Antioxidant therapy in human endocrine disorders. Med Sci Monit, 16(1), RA9-24.

He, T., Li, X., Wang, X., Xu, X., Yan, X., Li, X., ... \& She, G. (2020). Chemica composition and anti-oxidant potential on essential oils of Thymus quinquecostatus Celak. from Loess Plateau in China, regulating Nrf2/Keap1 signaling pathway in zebrafish. Scientific Reports, 10(1), 1-18 https://doi.org/10.1038/s41598-020-68188-8

Hleba, L., Vuković, N., Horská, E., Petrová, J., Sukdolak, S., \& Kačániová, M. (2014). Phenolic profile and antimicrobial activities to selected microorganisms of some wild medical plant from Slovakia. Asian Pacific Journal of Tropical Disease, 4(4), 269-274. https://doi.org/10.1016/S2222-1808(14)60571-5

Hleba, L., Kmet', V., Tóth, T., \& Kačániová, M. (2017). Resistance in bacteria and indirect beta-lactamase detection in E. coli isolated from Culex pipiens detected by matrix-assisted laser desorption ionization time of flight mass spectrometry. Journal of Environmental Science and Health, Part B, 52(1), 64-69. https://doi.org/10.1080/03601234.2016.1229466

Hlebová, M., Hleba, L., Medo, J., Kováčik, A., Čuboň, J., Charousová, I., ... \& Klouček, P. (2021). Antifungal and synergistic activities of some selected essential oils on the growth of significant indoor fungi of the genus Aspergillus. Journal of Environmental Science and Health, Part A, 1-12. https://doi.org/10.1080/10934529.2021.1994801

Höferl, M., Stoilova, I., Schmidt, E., Wanner, J., Jirovetz, L., Trifonova, D., ... \& Krastanov, A. (2014). Chemical composition and antioxidant properties of Juniper berry (Juniperus communis L.) essential oil. Action of the essential oil on the antioxidant protection of Saccharomyces cerevisiae model organism. Antioxidants, 3(1), 81-98. https://doi.org/10.3390/antiox3010081

Höferl, M., Stoilova, I., Wanner, J., Schmidt, E., Jirovetz, L., Trifonova, D., ... \& Krastanov, A. (2015). Composition and comprehensive antioxidant activity of ginger (Zingiber officinale) essential oil from Ecuador. Natural product communications, 10(6),

https://doi.org/10.1177/1934578X1501000672

$1934578 \times 1501000672$

Ighodaro, O. M., \& Akinloye, O. A. (2018). First line defence antioxidants superoxide dismutase (SOD), catalase (CAT) and glutathione peroxidase (GPX): Their fundamental role in the entire antioxidant defence grid. Alexandria journal of medicine, 54(4), 287-293. https://doi.org/10.1016/j.ajme.2017.09.001

Imelouane, B., Amhamdi, H., Wathelet, J. P., Ankit, M., Khedid, K., \& El Bachiri, A. (2009). Chemical composition and antimicrobial activity of essential oil of 
thyme (Thymus vulgaris) from Eastern Morocco. Int. J. Agric. Biol, 11(2), 205208.

Jambor, T., Arvay, J., Tvrda, E., Kovacik, A., Greifova, H., \& Lukac, N. (2021) The Effect of Apium Graveolens L., Levisticum Officinale and Calendula Officinalis L. on Cell Viability, Membrane Integrity, Steroidogenesis, and Intercellular Communication in Mice Leydig Cells in Vitro. Physiological Research, 70(4). https://doi.org/10.33549/physiolres.934675

Jamieson, D. J. (1998). Oxidative stress responses of the yeast Saccharomyces cerevisiae. Yeast, 14(16), 1511-1527. https://doi.org/10.1002/(SICI)1097 0061(199812)14:16<1511::AID-YEA356>3.0.CO;2-S

Khan, A., Ahmad, A., Khan, L. A., Padoa, C. J., van Vuuren, S., \& Manzoor, N. (2015). Effect of two monoterpene phenols on antioxidant defense system in Candida albicans. Microbial pathogenesis, 80, 50-56. https://doi.org/10.1016/j.micpath.2015.02.004

Kiokias, S., Proestos, C., \& Oreopoulou, V. (2020). Phenolic acids of plant origin-A review on their antioxidant activity in vitro (o/w emulsion systems) along with their in vivo health biochemical properties. Foods, 9(4), 534 https://doi.org/10.3390/foods9040534

Konuk, H. B., \& Ergüden, B. (2017). Antifungal activity of various essential oils against Saccharomyces cerevisiae depends on disruption of cell membrane integrity. Biocell, 41(1), 13. https://www.techscience.com/biocell/v41n1/33898 Kovacik, A., Gasparovic, M., Tvrda, E., Tokarova, K., Kovacikova, E., Rolinec, M., ... \& Galik, B. (2020). Effects of humic acid diet on the serum biochemistry and oxidative status markers in pheasants. Veterinární medicína, 65(6), 258-268. https://doi.org/10.17221/174/2019-VETMED

Kovacik, A., Tvrda, E., Miskeje, M., Arvay, J., Tomka, M., Zbynovska, K., ... \& Massanyi, P. (2019). Trace metals in the freshwater fish Cyprinus carpio: Effect to serum biochemistry and oxidative status markers. Biological trace element research, 188(2), 494-507. https://doi.org/10.1007/s12011-018-1415-x

Kovacikova, E., Kovacik, A., Halenar, M., Tokarova, K., Chrastinova, L. Ondruska, L., ... \& Kolesarova, A. (2019). Potential toxicity of cyanogenic glycoside amygdalin and bitter apricot seed in rabbits-Health status evaluation. Journal of animal physiology and animal nutrition, 103(2), 695-703. https://doi.org/10.1111/jpn.13055

Kulisic, T., Radonic, A., Katalinic, V., \& Milos, M. (2004). Use of differen methods for testing antioxidative activity of oregano essential oil. Food chemistry, 85(4), 633-640. https://doi.org/10.1016/j.foodchem.2003.07.024

Lis-Balchin, M., Deans, S. G., \& Eaglesham, E. (1998). Relationship between bioactivity and chemical composition of commercial essential oils. Flavour and Fragrance Journal, 13(2), 98-104. https://doi.org/10.1002/(SICI)10991026(199803/04)13:2<98::AID-FFJ705>3.0.CO;2-B

Lee, S. J., Umano, K., Shibamoto, T., \& Lee, K. G. (2005). Identification of volatile components in basil (Ocimum basilicum L.) and thyme leaves (Thymus vulgaris L.) and their antioxidant properties. Food Chemistry, 91(1), 131-137. https://doi.org/10.1016/j.foodchem.2004.05.056

Ložien, K., \& Venskutonis, P. R. (2003). Chemical composition of the essential oil of different varieties of thyme (Thymus pulegioides) growing wild in Lithuania. Biochemical Systematics and Ecology,31(3), 249-259. https://doi.org/10.1016/S0305-1978(02)00142-4

Lv, F., Liang, H., Yuan, Q., \& Li, C. (2011). In vitro antimicrobial effects and mechanism of action of selected plant essential oil combinations against four foodrelated microorganisms. Food Research International,44(9), 3057-3064. https://doi.org/10.1016/j.foodres.2011.07.030

Manuelian, C. L., Pitino, R., Simoni, M., Mavrommatis, A., De Marchi, M., Righi, F., \& Tsiplakou, E. (2021). Plant Feed Additives as Natural Alternatives to the Use of Synthetic Antioxidant Vitamins on Livestock Mammals' Performances, Health, and Oxidative Status: A Review of the Literature in the Last 20 Years. Antioxidants, 10(9), 1461. https://doi.org/10.3390/antiox10091461

Mar, P. D., El Khalfi, B., \& Soukri, A. (2020). Protective effect of oregano and sage essentials oils against the effect of extracellular $\mathrm{H} 2 \mathrm{O} 2$ and SNP in Tetrahymena thermophila and Tetrahymena pyriformis. Journal of King Saud University-Science, 32(1), 279-287. https://doi.org/10.1016/j.jksus.2018.05.005

Nikolić, M., Glamočlija, J., Ferreira, I. C., Calhelha, R. C., Fernandes, Â. Marković, T., ... \& Soković, M. (2014). Chemical composition, antimicrobial, antioxidant and antitumor activity of Thymus serpyllum L., Thymus algeriensis Boiss. and Reut and Thymus vulgaris L. essential oils. Industrial Crops and Products, 52, 183-190. https://doi.org/10.1016/j.indcrop.2013.10.006

Nour, V., Trandafir, I., \& Cosmulescu, S. (2017). Bioactive compounds, antioxidant activity and nutritional quality of different culinary aromatic herbs. Notulae Botanicae Horti Agrobotanici Cluj-Napoca,45(1), 179-184. https://doi.org/10.15835/nbha45110678

Oniga, I., Pușcaș, C., Silaghi-Dumitrescu, R., Olah, N. K., Sevastre, B., Marica, R., .. \& Hanganu, D. (2018). Origanum vulgare ssp. vulgare: Chemical

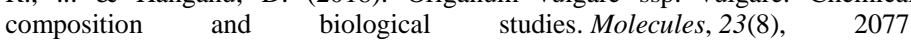
https://doi.org/10.3390/molecules23082077

Özcan, M., \& Erkmen, O. (2001). Antimicrobial activity of the essential oils of Turkish plant spices. European Food Research and Technology, 212(6), 658-660. https://doi.org/10.1007/s002170100310
Porte, A., \& Godoy, R. L. (2008). Chemical composition of Thymus vulgaris L. (Thyme) essential oil from the Rio de Janeiro state, Brazil. Journal of the Serbian Chemical Society, 73(3), 307-310. https://doi.org/10.2298/JSC0803307P Pratt, D. E. (1992). Natural antioxidants from plant material.

Sangun, M. K., Aydin, E., Timur, M., Karadeniz, H., Caliskan, M., \& Ozkan, A. (2007). Comparison of chemical composition of the essential oil of Laurus nobilis L. leaves and fruits from different regions of Hatay, Turkey. Journal of Environmental Biology, 28(4), 731-733.

Sefidkon, F., Abbasi, K., \& Khaniki, G. B. (2006). Influence of drying and extraction methods on yield and chemical composition of the essential oil of Satureja hortensis. Food chemistry, 99(1), 19-23. https://doi.org/10.1016/j.foodchem.2005.07.026

Spiridon, I., Colceru, S., Anghel, N., Teaca, C. A., Bodirlau, R., \& Armatu, A. (2011). Antioxidant capacity and total phenolic contents of oregano (Origanum vulgare), lavender (Lavandula angustifolia) and lemon balm (Melissa officinalis) from Romania. Natural product research,25(17), 1657-1661. https://doi.org/10.1080/14786419.2010.521502

Teixeira, B., Marques, A., Ramos, C., Serrano, C., Matos, O., Neng, N. R., ... \& Nunes, M. L. (2013). Chemical composition and bioactivity of different oregano (Origanum vulgare) extracts and essential oil. Journal of the Science of Food and Agriculture, 93(11), 2707-2714. https://doi.org/10.1002/jsfa.6089

Toledano, M. B., Delaunay, A., Biteau, B., Spector, D., \& Azevedo, D. (2003). Oxidative stress responses in yeast. In Yeast stress responses (pp. 241-303) Springer, Berlin, Heidelberg.

Tvrdá, E., Tušimová, E., Kováčik, A., Paál, D., Greifova, H., Abdramanov, A., \& Lukáč, N. (2016). Curcumin has protective and antioxidant properties on bull spermatozoa subjected to induced oxidative stress. Animal reproduction science, 172, 10-20. https://doi.org/10.1016/i.anireprosci.2016.06.008

Vizzari, F., Massányi, M., Knížatová, N., Corino, C., Rossi, R., Ondruška, L., ... \& Massányi, P. (2021). Effects of dietary plant polyphenols and seaweed extract mixture on male-rabbit semen: Quality traits and antioxidant markers. Saudi $\begin{array}{llll}\text { Journal of } & \text { Biological } & \text { Sciences, 28(1), }\end{array}$ https://doi.org/10.1016/j.sjbs.2020.11.043

Wang, X. W., Du, H. Y., Song, Y. H., \& Ma, Z. S. (2011). Antimicrobial activity of oregano ossential oil, carvacrol, citral and cinnamaldehyde [J]. Food science and technology, 2

Yan, C., Chen, X. Y., Sui, H., Yu, X. T., Wang, Y., Bai, S. J., ... \& She, G. M (2016). Antioxidant activities and chemical compositions of Thymus quinquecostatus Celak. J. Beijing Univ. Tradit. Chin. Med, 39(5), 383-389.

Zhang, R., Wang, X. W., Liu, L. L., Cao, Y. C., \& Zhu, H. (2020). Dietary oregano essential oil improved the immune response, activity of digestive enzymes, and intestinal microbiota of the koi carp, Cyprinus carpio. Aquaculture, 518, 734781 https://doi.org/10.1016/j.aquaculture.2019.734781

Zhong, R. Z., \& Zhou, D. W. (2013). Oxidative stress and role of natural plant derived antioxidants in animal reproduction. Journal of integrative agriculture, 12(10), 1826-1838. https://doi.org/10.1016/S2095-3119(13)60412-8 